\title{
The Life Cycles of Mayflies (Insecta: Ephemeroptera) of the Eastern Ukraine. Second Report
}

\author{
Alexander V. Martynov \\ National Museum of Natural History, National Academy of Sciences of Ukraine (Kyiv, Ukraine)
}

The Life Cycles of Mayflies (Insecta: Ephemeroptera) of the Eastern Ukraine. Second Report. Martynov, A. V. - This article is the second report on the results of investigation of mayflies' life cycles in Eastern Ukraine. It is shown, that different methods should be used to determine the larval age of the representatives of different families. The paper presents data on life cycles of 18 mayfly species; the larval age structure change during a year for five of these species (Cloeon dipterum, Centroptilum luteolum, Paraleptophlebia submarginata, Ecdyonurus dispar gratificus and Ephemera vulgata) was investigated in detail in model waterbodies. The flight periods of imagoes of investigated species within the Eastern Ukraine are given. Some features of swarming in Leptophlebia marginata and Kageronia fuscogrisea are described. It is shown, that rare European species Metreletus balcanicus has monovoltine life cycle within the region, and overwinters at the egg stage (Us). It is established, that ovoviviparous Cloeon dipterum has 2-3 generations per year (MB-MP) within Eastern Ukraine; the voltinity depends mainly on water temperature in every concrete waterbody. The main part of population of monovoltine Ecdyonurus dispar gratificus overwinters as the egg stage, small its part - as the larval stage.

Key words: mayflies, Ephemeroptera, life cycles, bionomy, voltinity, Eastern Ukraine.

\section{Introduction}

At the present moment a considerable attention is paid to investigation of life cycles of mayflies. The type of life cycle of many mayfly species can vary within their areals (Clifford, 1982; Elliott et al., 1988; Bauernfiend \& Soldán, 2012; etc.). Therefore it is important to study the peculiarities of development of Ephemeroptera within every region, where the detailed investigations are planned. The information on life cycles allow to determine the most appropriate time for faunistic research in a region. Also, these data can be used for bioindication and for investigation of ecological pliability of species within a region and whole areal.

This article is the second report on the results of investigation of mayflies' life cycles in Eastern Ukraine (Martynov, 2013).

\section{Material and methods}

Material was collected in Donetsk, Lugansk and parts of Zaporizhnya and Kharkiv regions of Ukraine during 2007-2016. For the investigation the age structure change of larvae of 5 species (Table 1), fourteen samples of each species were taken from model waterbodies from March, 2010 to March, 2011 (not less than once a month, except of winter months in some cases). The data on temperature change during the year in model waterbody Bulavina River (vicinity of Debaltseve) are given in our previous work (fig. 6 in Martynov, 2013); for the model pound in vicinity of Mineral'ne village - in present paper (Fig. 2 ).

The classification of life cycles used in this paper follows H. F. Clifford (1982). The coordinates of model water bodies are given by accessible Internet-program «Google Earth» (http://earth.google. com).

Age structure definition. The change of age structure for mayfly larvae during the year has been studied using the system by K. Jop (1981) with some our previous (Martynov, 2013) and current alternations (Fig. 1).

Corresponding author address: A. V. Martynov; National Museum of Natural History, National Academy of Sciences of Ukraine; Bohdan Khmelnitsky St. 15, Kyiv, 01601 Ukraine; e-mail: martynov_av@ukr.net 
In Cloeninae and Leptophlebiidae 9 age groups (L0 to L8) of larvae were used (Fig. 1), previously distinguished for subfamily Baetinae (Martynov, 2013 - erroneously given as 10 age groups in the text; all figures on age structure change in this article are correct).

In Ecdyonurus gratificus (Heptageniidae) 13 age groups were distinguished (L0 to L12) (Fig. 1). Larvae ready to become winged with completely developed wings inside the pads occurred only in L12 group, therefore four groups of larval ages were added to the previous system present in our article about life cycles of Baetinae species (Martynov, 2013).

Table 1. Model waterbodies and material used for the investigation of age structure change of mayfly larvae during the year

Таблиия 1. Модельні водойми та об'єм матеріалу, що були використані для вивчення зміни вікової структури личинок одноденок протягом року

\begin{tabular}{|c|c|c|c|c|}
\hline Species & $\begin{array}{c}\text { Administrative location } \\
\text { of waterbody }\end{array}$ & Waterbody & Coordinates & $\begin{array}{l}\text { Number of } \\
\text { specimens }\end{array}$ \\
\hline Cloeon dipterum & $\begin{array}{c}\text { Ukraine, Donetsk region (oblast), } \\
\text { Yasynuvata district (raion), vicinity } \\
\text { of Mineral'ne village }\end{array}$ & pound & $\begin{array}{l}48^{\circ} 05^{\prime} 48^{\prime \prime} \mathrm{N} \\
37^{\circ} 49^{\prime} 53^{\prime \prime} \mathrm{E}\end{array}$ & 1269 \\
\hline $\begin{array}{l}\text { Centroptilum luteolum } \\
\text { Paraleptophlebia submarginata } \\
\text { Ecdyonurus dispar gratificus } \\
\text { Ephemera vulgata }\end{array}$ & $\begin{array}{c}\text { Ukraine, Donetsk region (oblast), } \\
\text { Bakhmut district (raion), vicinity of } \\
\text { Debaltseve urban village }\end{array}$ & $\begin{array}{l}\text { rhithral zone of } \\
\text { Bulavina River }\end{array}$ & $\begin{array}{l}48^{\circ} 18^{\prime} 55^{\prime \prime} \mathrm{N} \\
38^{\circ} 26^{\prime} 07^{\prime \prime} \mathrm{E}\end{array}$ & $\begin{array}{l}275 \\
245 \\
423 \\
741\end{array}$ \\
\hline
\end{tabular}

In Ephemera vulgata the ratios of lengths of body and wing pads at larvae of different edges are insignificant. As the result, only the body length (without caudal filaments) was used for the determination of larval age groups in this species following J. Alba-Tercedor (1990) and A. Haybach (2006).

To show the larvae ready to emerge (having completely developed wings inside the pads), and/or winged stages the inclined black arrow was added above the dates of sampling in the histograms of age structure change for each species.

The spreadsheet designed by A. Buffangi on the base of Microsoft Office Excel (Tools, 2012) was used for generation of histograms, which reflect the larvae age structure during the year.

\section{Results and discussion}

\section{Metreletus balcanicus (Ulmer, 1920)}

Very rare species in Ukraine; known only from one locality in Kharkiv region for now (Мартынов, 2011). In Eastern Ukraine species has one generation per year and overwinters as the egg stage (Us). Larvae begin to hatch in March. Larvae of middle and elder ages are recorded in middle of April.

The species demonstrates two types of monovoltine life cycles within the nearby European countries (Poland and Czech Republic): overwintering only as the stage of egg (Us) and overwintering as the larvae and eggs (Us-Uw) (Soldán, 1978; Jażdżewska \& Wojcieszek, 1997; Soldán \& Zahrádková, 2000).

\section{Centroptilum luteolum (Müller, 1776)}

The species has two types of life cycles (MBws and Uw-MBws) within Eastern Ukraine.

Bivoltine life cycle, with overwintering as the larval stage (MBws) C. luteolum mainly has throughout Europe (Landa, 1969; Sowa, 1975; Söderström, 1991; Alba-Tercedor, 1984; Soldán \& Zahrádková, 2000; etc.), but in some waterbodies of Poland species is monovoltine (Uw) (Jop, 1981) and in some waterbodies of Spain - polyvoltine (MP) (Alba-Tercedor, 1984). The MP life cycle was also registered for C. luteolum in North Africa (Bauernfiend \& Soldán, 2012).

Our investigation of larval age structure (Fig. $2 a$ ) and change of their quantitative representation in the rhithral zone of Bulavina River showed that the species has Uw-MBws life cycle in this type of waterbodies. In the rhithral zone the main part of eggs laid by imagoes of the first generation diapauses up to autumn, but the small part of this eggs give rise to the larvae of the second generation. The flight of imago of the second generation occurs at the end of summer. After some time their eggs 


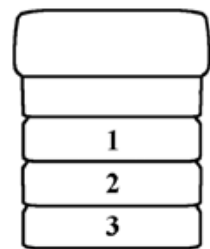

L0

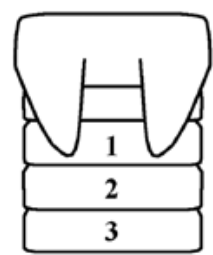

L5

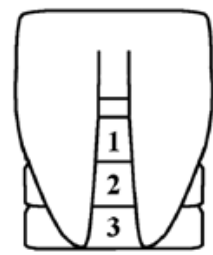

L10

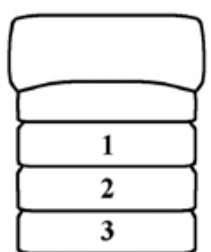

L1

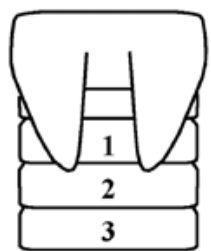

L6

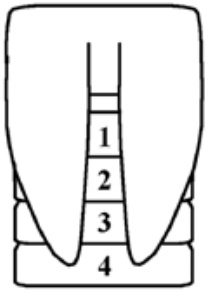

L11

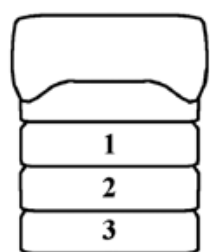

L2

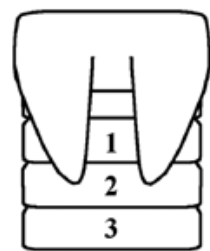

L7
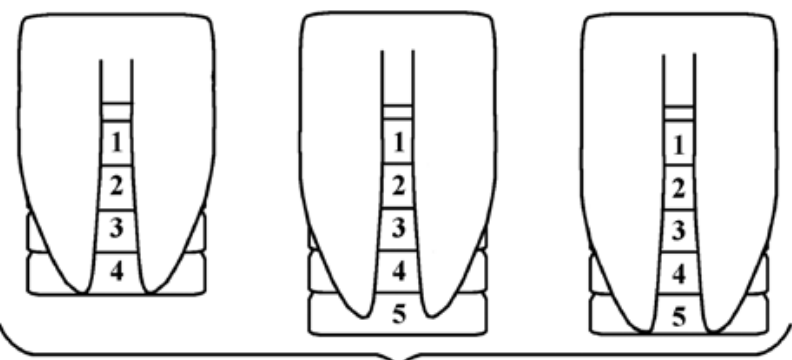

L12

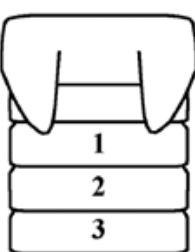

L4

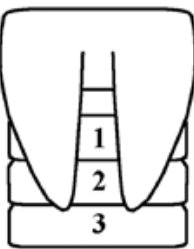

L8

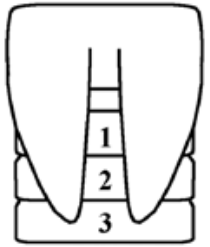

L9

Fig. 1. The developmental degree of wing pads of larvae in different age groups. $1-5-$ abdominal segments; L0-L12 - age groups.

Рис. 1. Ступінь розвитку крилових зачатків у личинок одноденок різних вікових груп. 1-5 - сегменти черевця; L0-L12 - вікові групи.

give rise to larvae. At the same time the eggs of the first generation come out from the diapause and produce larvae too. All these larvae overwinter consequently.

Generally, the larvae ready to emerge and winged stages of C. luteolum are registered in Eastern Ukraine from the middle of April to the end of May and from the first decade of July to the end of August. The highest number of flighing specimens are recoded in the middle of May. Larvae of different ages in different quantity are registered in rhithral warerbodies during whole year.

\section{Cloeon dipterum (Linnaeus, 1761)}

Cloeon dipterum is the ovoviviparous species. Its larvae are registered in waterbodies during the whole year. Within all area of distribution C. dipterum has different types of life cycles (Clifford, 1982). In Europe it has mainly bivoltine life cycle, overwintering as the larval stage (MBws) (Landa, 1968, 1968; Elliott et al., 1988; Soldán \& Zahrádková, 2000; Bauernfiend \& Soldán, 2012). In waterbodies of Norway species is monovoltine life cycle (Uw) (Brittain, 1974) and in some waterbodies of Poland and Germany - polyvoltine (MB-MP) (Sowa, 1975; Haybach, 1998).

In some East Ukrainian waterbodies $C$. dipterum has 2-3 generations per year and MB-MP life cycle; in some relatively coldwater bodies it gives only two generations per year, having MBws life cycle. Voltinity of species in every concrete case depends on water temperature (and its change during the year) and plentity of food base for the larvae. The statement about the possibility of having of three generations in a year for the species was made by studying the changes in the age structure of larvae during the year, whose development took place in the well-heated pond (Fig. $2 c$ ). The temperature in this pound reaches $29^{\circ} \mathrm{C}$ in summer (Fig. $2 d$ ). There are many algae and detritus in it. As it seen on fig. $2 b$, larvae of first ages (L0), which have high rate of growth, occur mainly from the middle 
of May to middle of November in the Eastern Ukraine. The larvae ready for emergence and winged stages of $C$. dipterum are commonly registered from May to the end of September, in the biggest quantities - at the ends of May and July. Absence of distinct gaps between flight periods of imagoes of first-third generations and between registration of larvae of first ages of these generations are the result of high variability in duration of larval development (as result the emergence of winged stages of each generation is prolonged) and absence of egg diapause. Research of S. Cianciara $(1979,1980)$ and J. M. Hwang et al. (2005) showed that the duration of larval development is highly dependent on the type of food and temperature, and ranges from 2 to 10 month.

In Eastern Ukraine $C$. dipterum overwinters as the larvae of junior and middle ages. This species, as other representatives of the order with bi- or polyvoltine life cycles, overwintering as the larval stage, is characterized by the significantly larger mature overwintered larvae of first generation if compared with those of second and third not overwintering generations (Cianciara, 1979; Hwang et al., 2005; Martynov, 2013).
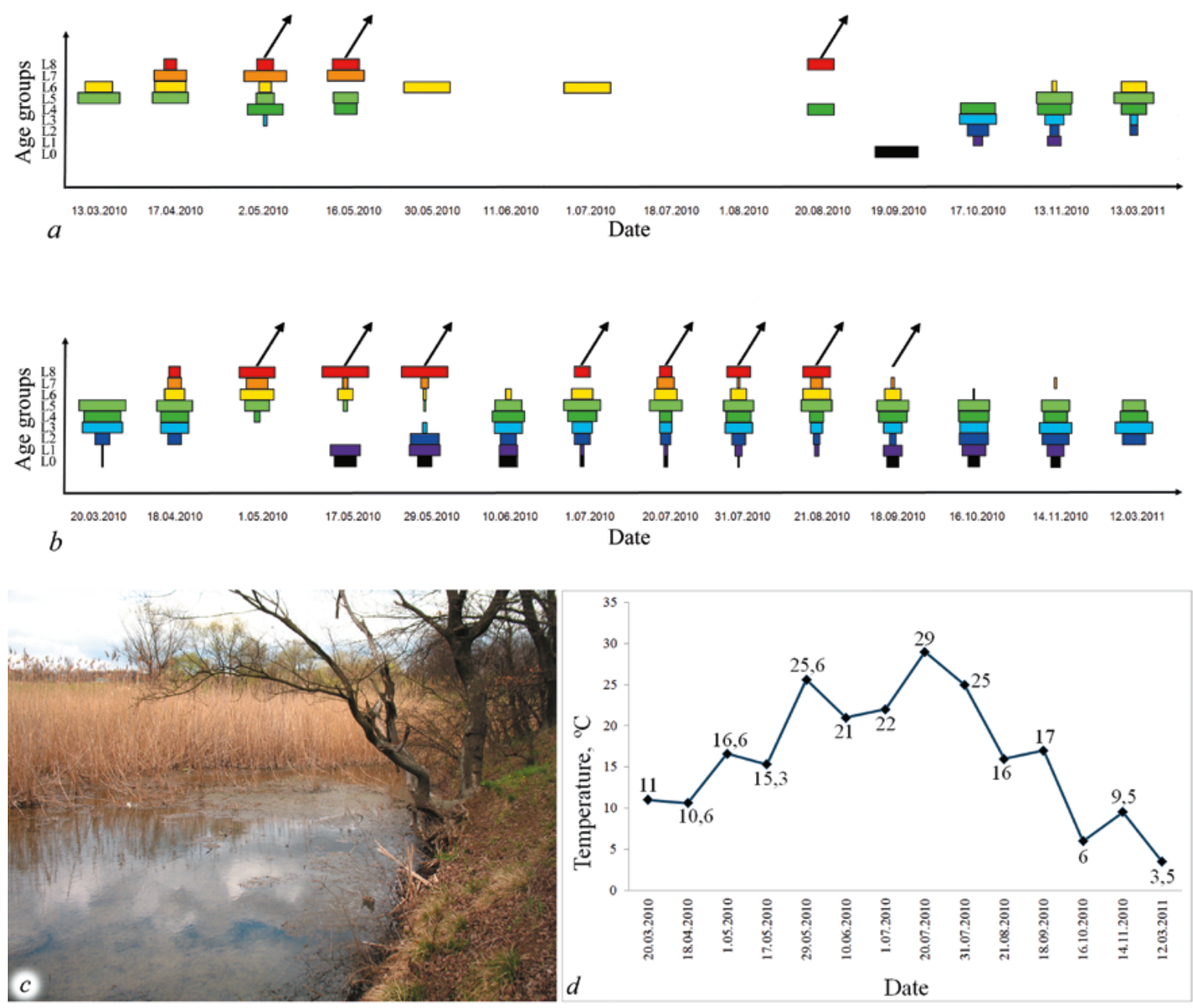

Fig. 2. The age structure change of larvae of two species during the year and features of one of the model waterbodies: $a$ - the age structure change of Centroptilum luteolum larvae during the year, the rhithral zone of Bulavina River (vicinity of Debaltseve urban village, 2010-2011); $b$ - the age structure change of Cloeon dipterum larvae during the year, pound (vicinity of Mineral'ne village, 2010-2011); $c$ - total view of model pound in vicinity of Mineral'ne village; $d$ - water temperature change in the model pound during the year.

Рис. 2. Зміна вікової структури личинок двох видів протягом року та особливості одного з модельних водойм: $a$ - Centroptilum luteolum, ритральна зона річки Булавіна (окол. смт Дебальцеве, 2010-2011 рр.); $b$ - Cloeon dipterum, ставок (окол. с. Мінеральне, 2010-2011 рр.); $c$ - зовнішній вигляд модельного ставку в околицях с. Мінеральне; $d-$ зміна температури води у модельному ставку протягом року. 


\section{Cloeon simile Eaton, 1870}

This species is known by a few findings in the region (Мартынов, 2014). Middle and elder larval ages were registered in October and November, thus the species overwintered as larvae. Voltinity of C. simile in Eastern Ukraine is unknown.

Within Europe species often has bivoltine life cycle, overwintering as the larval stage (MBws) (Sowa, 1975; Elliott et al., 1988; Haybach, 1998; Soldán \& Zahrádková, 2000; etc.), but it also can have the polyvoltine (MP) and both types of monovoltine life cycles (Uw and Us) (Bauernfiend \& Soldán, 2012).

\section{Heptagenia flava Rostock, 1878}

Within the Eastern Ukraine species has monovoltine life cycle, overwintering as the larval stage (Uw). It has the same life cycle within vast part of the areal (Landa, 1968, 1969; Sowa, 1975; Haybach, 1998; Bauernfiend \& Soldán, 2012). According to some researchers, the long (near 5 months) flight period of imago can be considered as an indicator of bivoltinity of the species (Soldán \& Zahrádková, 2000). In the Eastern Ukraine larvae ready for emergence and winged stages are registered from the beginning of May to end of July. Larvae of different ages are recoded in the region during a whole year.

\section{Heptagenia longicauda (Stephens, 1835)}

In Eastern Ukraine $H$. longicauda has monovoltine life cycle, overwintering as the larval stage (Uw). Larvae ready for emergence and winged stages are registered from third decade of May to the first decade of August.

The life cycle of the species is poorly investigated in Europe. It was supposed that $H$. longicauda has monovoltiny life cycle, overwintering as the larval stage (Uw). As in the case of $H$. flava, some researchers suppose that $H$. longicauda can has bivoltine life cycle (MBws) (Landa, 1968, 1969; Haybach, 1998; Soldán \& Zahrádková, 2000; Bauernfiend \& Soldán, 2012).

\section{Kageronia fuscogrisea (Retzius, 1783)}

Within Europe species has monovoltine life cycle, overwintering at the larval stage (Uw) (Landa, 1969; Brittain, 1974; Sowa, 1975; Jop, 1981; Bauernfiend \& Soldán, 2012; etc.). Despite the scanty data on K. fuscogrisea from Eastern Ukraine we can say that it has the same life cycle (Uw) within this territory.

Mass emergence and imagoes' fligth of species were registered by us in the first decade of May. Imagoes formed a small swarm (consisting of 3-7 specimens), which held on high of 2-3 meters near the border of bank and water. During the mass flight the swarms can be located close to each other, but they never unite.

\section{Ecdyonurus dispar gratificus Martynov \& Godunko, 2013}

Currently known areal of subspecies is restricted by Donetsk Elevated physiographic area (Martynov \& Godunko, 2013). Ecdyonurus dispar gratificus has monovoltine life cycle, vast part of its population overwinters as the egg, and small part - as the larval stage (Uw-Us). Larvae of subspecies can be registered during whole year in waterbodies of Eastern Ukraine. Larvae begin to hatch from overwintered eggs in the end of May and go on hatching to the middle of July (Fig. $3 a$ ). Older ages of larvae, subimagoes and imagoes occur from the end of May to the middle of September. The most active growth of larvae is registered in summer months. Mature larvae, which come from overwintered eggs, are smaller than those, which come from overwintered larvae.

\section{Leptophlebia marginata (Linnaeus, 1767)}

Within the Eastern Ukraine species has monovoltine life cycle, overwintering as the larval stage (Uw). The same type of the life cycle noted for this species in other European countries (Solem, 1973; Brittain, 1974; Elliott et al., 1988; Söderström, 1991; Bauernfiend \& Soldán, 2012; etc.).

In target territory the larvae ready for emergence and flight of imagoes are registered from the second half of April to the beginning of June. The higher quantities of emerging winged stages are recoded in the first decade of May.

Males of L. marginata swarm mainly on meadows and glades in river valleys; swarms are never registered above the water surface. During the mass flight the swarms of L. marginata comprise 20-50 specimens, but sometimes they can be much bigger: a swarm almost 15 meters hight consisting of about 1000 specimens were registered by us in 2011 at the valley of Oskol River (Kharkiv region). 

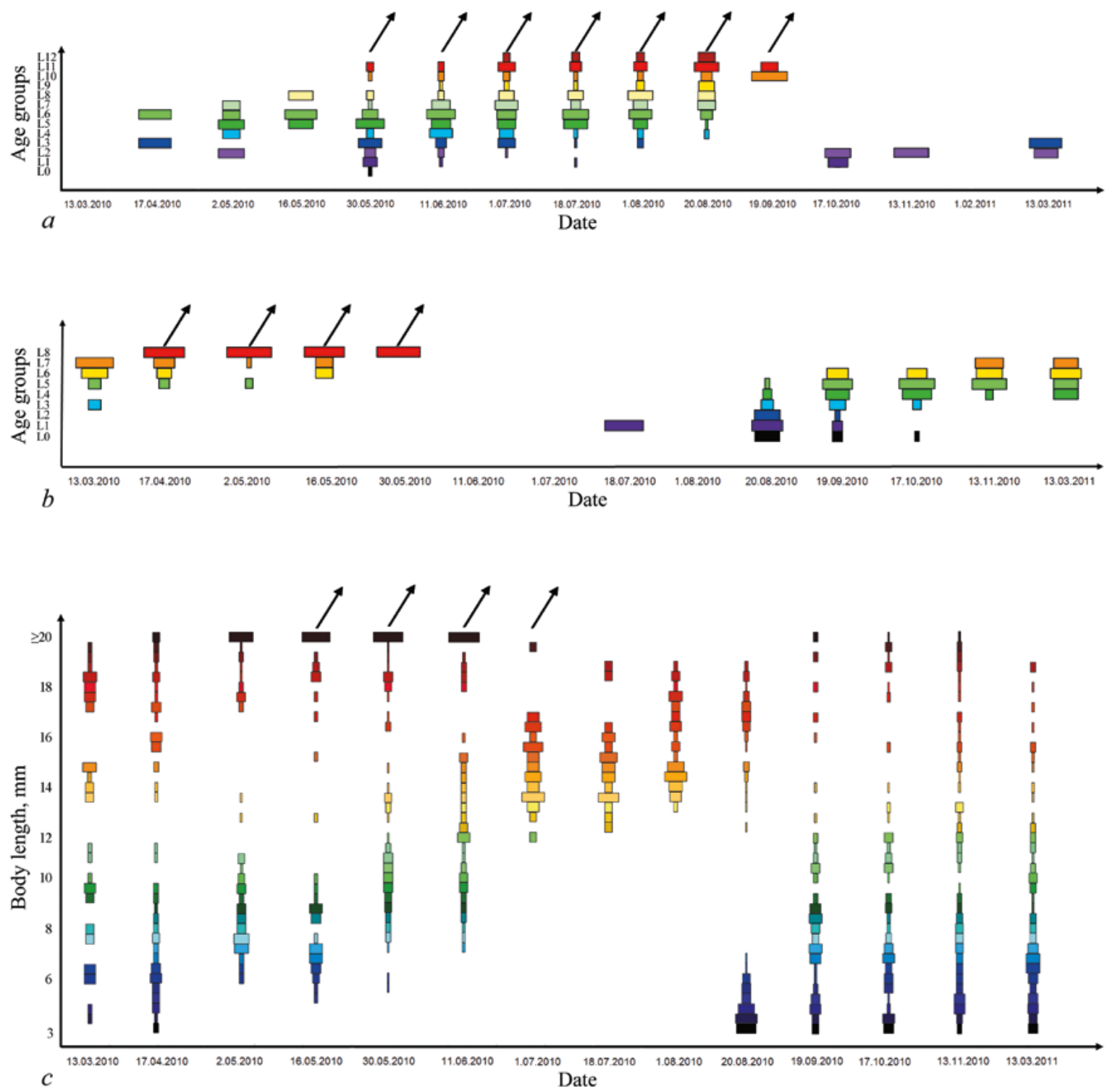

Fig. 3. The age structure change of larvae of Ecdyonurus dispar gratificus (a), Paraleptophlebia submarginata (b) and Ephemera vulgata (c) during the year in the rhithral zone of Bulavina River (vicinity of Debaltseve urban village, 2010-2011).

Рис. 3. Зміна вікової структури личинок Ecdyonurus dispar gratificus (a), Paraleptophlebia submarginata (b) та Ephemera vulgata (c) протягом року у ритральній зоні річки Булавіна (окол. смт Дебальцеве) (2010-2011 pp.).

\section{Leptophlebia vespertina (Linnaeus, 1758)}

Leptophlebia vespertina is the very rare species in Eastern Ukraine. Its imagoes were registered only in May. Within region, as in Europe (Solem, 1973; Jop, 1981; Elliott et al., 1988; Soldán \& Zahrádková, 2000; Bauernfiend \& Soldán, 2012; etc.), the species has monovoltine life cycle, overwintering as the larval stage (Uw).

\section{Paraleptophlebia submarginata (Stephens, 1835)}

Our analysis of the changes in the age structure of the larvae during the year (Fig. $3 b$ ) and imagoes' flight period in the region, gave the possibility to conclude that in the Eastern Ukraine $P$. submarginata has monovoltine life cycle, overwintering as the larval stage (Uw). The same life cycle the species has in other European countries (Sowa, 1975; Elliott et al., 1988; Haybach, 1998; Soldán 
\& Zahrádková, 2000; Bauernfiend \& Soldán, 2012; etc.). In the regional fauna the larvae ready for emergence and winged stages of P. submarginata are registered from the middle of April to the end of May, in highest quantities - in the first decade of May. Hatching of vast part of larvae is recorded in the second half of August. A single record of larvae of early ages dated by the middle of July (Fig. $3 b$ ) is rather an exception, than a rule, and does not prove the bivoltinity of species. The example of the Bulavina River shows that the most intensive growth of larvae in rhithral zone of regional rivers is observed in the end of summer-autumn (Fig. $3 \mathrm{~b}$ ), before the significant lowering of the water temperature in the waterbodies (fig. 6 in Martynov, 2013).

\section{Paraleptophlebia werneri Ulmer, 1919}

This species has monovoltine life cycle, overwintering as the eggs (Us) in the Eastern Ukraine. Larvae ready for emergence and winged stages of $P$. werneri are registered here from the third decade of May to the middle of July, with the highest quantities of specimens in the end of May.

Within other European countries Paraleptophlebia werneri has the same life cycle (Us) (Landa, 1968, 1969; Bauernfiend \& Soldán, 2012), but some researchers suppose that species overwinters as the larval stage and like P. submarginata and P. cincta it has Uw life cycle (Landa, 1968, 1969).

\section{Ephemera vulgata Linnaeus, 1758}

In Eastern Ukraine, as in Europe (Landa, 1969; Sowa, 1975; Elliott et al., 1988; Soldán \& Zahrádková, 2000; Bauernfiend \& Soldán, 2012; etc.), Ephemera vulgata has semivoltine life cycle (2Y) - its larvae develop for two years. In the regional fauna the flight period of imago is relatively short - larvae ready for emergence and winged stages are registered from the end of May to the beginning of July. Larvae hatch from eggs in August (Fig. $3 c$ ). The most intensive growth of overwintered larvae in rhithral zone of East-Ukrainian waterbodies is observed from the end of May to beginning of August (Fig. 3 c) under the highest values of the water temperature (fig. 6 in Martynov, 2013).

\section{Serratella ignita (Poda, 1761)}

Serratella ignita is very rare within Eastern Ukraine, inhabits only waterbodies within Donetsk Elevated physiographic area (Мартынов, 2014). It likely has monovoltine life cycle. Mature larvae and winged stages are registered in the middle of July. For the present moment, it is impossible to determine the overwintering stage for the species because of its rarity in the region.

Within Europe S. ignita is highly ecologically flexible and inhabits different types of waterbodies, and therefore demonstrates the variety of life cycles - Us, MBss, MBws and Us-(Uw). The species can have one or two generations per year, overwintering as the larval stage or as eggs or as both these stages simultaneously (Jażdżewska, 1980; Jop, 1981; Elliott et al., 1988; Sartori \& Landolt, 1999; Bauernfiend \& Soldán, 2012; etc.).

\section{Caenis horaria (Linnaeus, 1758)}

In Europe the species has from one to three generations per year, but in all cases it overwinters as the larval stage (Uw, MBws and MB-MP) (Jażdżewska, 1971; Malzacher, 1986; Haybach, 1998; Soldán \& Zahrádková, 2000; Bauernfiend \& Soldán, 2012; etc.). Within Eastern Ukraine C. horaria is bivoltine, overwintering as the larval stage (MBws). Larvae ready for emergence and winged stages are registered in the region from the end of April to the middle of August.

\section{Caenis robusta Eaton, 1884}

In Europe the species has three types of life cycles: mono- and bivoltine, overwintering as the larval stage (Uw and MBws) and bivoltine, overwintering as the eggs (MBss) (Malzacher, 1986; Elliott et al., 1988; Soldán \& Zahrádková, 2000; Bauernfiend \& Soldán, 2012; etc.). Its most common type of life cycle is MBws.

Within the Eastern Ukraine larvae ready for emergence and winged stages of C. robusta are registered from the second decade of May to the third decade of August; such long flight period evidences of the bivoltinity of species in the region. Registration of its larvae in early spring and late autumn is caused by the wintering at this stage. Therefore, within the region under investigation C. robusta has bivoltine life cycle overwintering as the larval stage (MBws). 


\section{Caenis luctuosa (Burmeister, 1839)}

In Europe C. luctuosa has two types of life cycles: mono- and bivoltine, overwintering as the larval stage in both cases (Uw and MBws) (Brittain, 1974; Malzacher, 1986; Soldán \& Zahrádková, 2000; Bauernfiend \& Soldán, 2012; etc.).

Within the Eastern Ukraine species has bivoltine life cycle, overwintering as the larval stage. Larvae ready for emergence were registered here in the beginning of May and from the beginning of August to the middle of September. The recoded flight periods of both generations are somewhat short, and their limits remain uncertain because of the rarity of species.

\section{Caenis macrura Stephens, 1835}

Within Europe the species has two types of life cycles: mono- and bivoltine, overwintering as the larval stage in both cases (Uw and MBws) (Malzacher, 1986; Soldán \& Zahrádková, 2000; Bauernfiend \& Soldán, 2012; etc.).

In Eastern Ukraine larvae ready for emergence and winged stages of $C$. macrura are registered from the end of June to the middle of September. Species overwinters as the larval stage. The insufficient data on flight periods of imago do not give possibility to determine reliably the number of generations per year, but we can suppose that $C$. macrura gives two generation per year in the Eastern Ukraine.

We could not determine the types of life cycles and the significant aspects in phenology of Procloeon pennulatum (Eaton, 1870), Paraleptophlebia cincta (Retzius, 1783), Ephemera lineata Eaton, 1870 and Ephoron virgo (Olivier, 1791) within Eastern Ukraine, because of their high rarity in the region.

\section{Conclusions}

Rare European species Metreletus balcanicus has monovoltine life cycle and overwinters as the egg stage (Us) in the Eastern Ukraine.

Ecdyonurus dispar gratificus, an endemic of Donetsk Elevated physiographic area, has mixed type of monovoltine life cycles - Uw-Us: main part its population winters as the egg stage and small part - as the larval stage.

In Cloeon dipterum the number of generations per year can vary from to 2 to 3 within Eastern Ukraine. The voltinity of species depends mainly on water temperature in concrete waterbody.

The results of present and previous (Martynov, 2013) investigations can be used in faunistic, ecological and bioindicational research in Eastern Ukraine. Given information on the life cycles allow to determine the most appropriate time for faunistic research in the region. Also, these data can be and for investigation of ecological pliability of species within a region and whole areal.

\section{Literature}

Мартынов, А. В. Обзор поденок (Insecta, Ephemeroptera) Харьковской области (Украина) // Природничий альманах. Біологічні науки, випуск 16. Збірник наукових праць. - Херсон, ПП Вишемирський, 2011. - C. 72-92.

[Martynov, A. V. Overview of mayflies (Insecta, Ephemeroptera) of Kharkiv region (Ukraine) // Nature Almanac. Series: Biological Sciences. - 2011. - N 16. - P. 72-92. (in Russian, with English summary)]

Мартынов, A. В. Поденки (Ephemeroptera) ритральной и кренальной зон водотоков Донецкой возвышенной физико-географической области (Восточная Украина): видовой состав, экологические особенности // Кавказский Энтомологический Бюллетень. - 2014. - Том 10, Вып. 1. - С. 3-18.

[Martynov, A. V. Mayflies (Ephemeroptera) of Rhithral and Crenal Zones of Donetsk Elevated Physiographic Area's Watercourses (Eastern Ukraine): species composition, ecological characteristics // Caucasian Entomological Bulletin. - 2014. - Vol. 10, N 1. - P. 3-18. (in Russian, with English summary)]

Alba-Tercedor, J. Ecología, distribución y ciclos de desarrollo de efemerópteros de Sierra Nevada (Granada, España). II: Baetidae (Insecta, Ephemeroptera) // Limnética. - 1984. - Vol. 1. - P. 234-246.

Alba-Tercedor, J. Life cycles and ecology of some species of Ephemeroptera from Spain // Mayflies and Stoneflies: Life histories and biology. - Dordrecht: Kluwer Academic Publishers, 1990. — P. 13-16.

Bauernfiend, E., Soldán, T. The Mayflies of Europe (Ephemeroptera). - Ollerup: Apollo Books, 2012 . - 781 pp. Brittain, J. E. Studies on the lentic Ephemeroptera and Plecoptera of southern Norway // Norsk Entomologiske Tidsskrift. - 1974. - Vol. 21. - P. 135-154.

Cianciara, S. Life cycles of Cloeon dipterum (L.) in natural environment // Polskie Archiwum Hydrobiologii. 1979. - Vol. 26, N 4. - P. 501-513. 
Cianciara, S. Food preference of Cloeon dipterum (L) larvae and dependence of their development and growth on the type of food // Polskie Archiwum Hydrobiologii. - 1980. - Vol. 27, N 1. - P. 143-160.

Clifford, H. F. Life cycles of mayflies (Ephemeroptera), with special reference to voltinism // Quaestiones Entomologicae. - 1982. - Vol. 18, N 1-4. - P. 15-90.

Elliott, J. M., Humpesch, U. H., Macan, T. T. Larvae of the British Ephemeroptera: a key with ecological notes // Freshwater Biological Association. Scientific publication N 49. - 1988. - P. 1-145.

Haybach, A. Die Eintagsfliegen (Insecta: Ephemeroptera) von Rheinland - Pfalz - Zoogeographie, Faunistik, Ökologie, Taxonomie und Nomenklatur - Unter besonderer Berücksichtigung der Familie Heptageniidae und unter Einbeziehung der übrigen aus Deutschland bekannten Arten: Dissertation am Fachbereich Biologie; Prüfung 20.10.1998. - Mainz, 1998. - 417 p.

Haybach, A. Life cycle and timing of emergence of Oligoneuriella rhenana (Imhoff, 1852) in the Kyll River (SWGermany) [Ephemeroptera: Oligoneuriidae] // Ephemera. - 2005 (2006). - Vol. 7, N 1. - P. 1-7.

Hwang, J. M., Lee, S. J., Bae, Y. J. Larval growth of Cloeon dipterum (Ephemeroptera: Baetidae) in different temperature contiditions // Korean Journal of Environmental Biology. - 2005. - Vol. 23, N 2. - P. 114-119.

Jażdżewska, T. Jetki (Ephemeroptera) rzeki Grabi. Mayflies (Ephemeroptera) of the River Grabia // Polskie Pismo Entomologiczne. - 1971. - Vol. 41, N 2. - P. 243-304.

Jażdżewska, T. Structure et functionnement des écosystèmes du Haut-Rhône français. 17. — Le cycle vital d'Ephemerella ignita (Poda 1761) (Ephemerellidae, Ephemeroptera) dans le Rhône lyonnais // Bulletin d'Écologie. - 1980. - Vol. 11, N 1. - P. 33-43.

Jażdżewska, T., Wojcieszek, A. Metreletus balcanicus (Ulmer, 1920) (Ephemeroptera) in Poland with notes on its ecology and biology // Polskie Pismo Entomologiczne. - 1997. - Vol. 66. - P. 9-16.

Jop, K. Ecology of the forest stream Lane Błato in the Niepołomice Forest // Acta Hydrobiologica. - 1981. Vol. 23, N 2. - P. 125-141.

Landa, V. Developmental cycles of Central European Ephemeroptera and their interrelations // Acta Entomol. Bohemoslov. - 1968. - Vol. 65, N 4. - P. 276-284.

Landa, V. Jepice - Ephemeroptera. Fauna CSSR. - Praha, 1969. - Vol. 18. - P. 1-349.

Malzacher, P. Diagnostik, Verbreitung und Biologie der europäischen Caenis-Arten (Ephemeroptera: Caenidae) // Stuttgarter Beiträge zur Naturkunde. Ser.A-Biologie. - 1986. - N 387. - P. 1-41.

Martynov, A. V. The life cycles of mayflies of the Eastern Ukraine. Subfamily Baetinae (Ephemeroptera, Baetidae) // Vestnik zoologii. - 2013. - Vol. 47, N 1. - P. 39-48.

Martynov, A. V \& Godunko, R. J. A new subspecies of the subgenus Ecdyonurus Eaton, 1868 (Ephemeroptera: Heptageniidae) from the East of Ukraine // Zootaxa. - 2013. - Vol. 3666, N 4. - P. 489-509.

Sartori, M., Landolt, P. Atlas de distribution des Ephemeres de Suise (Insecta, Ephemeroptera). Fauna Helvetica. - 1999. - Vol. 3. - SEG-CSCF ed. Neuchâtel. - 214 p.

Söderström, $O$. Life cycles and nymphal growth of twelve coexisting mayfly species in a boreal river // Overview and strategies of Ephemeroptera and Plecoptera. — Gainesville (Florida): Sandhill Crane Press, 1991. - P. 503-514.

Soldán, T. Mayflies (Ephemeroptera) new to the fauna of Czechoslovakia found in 1972-1977 // Acta Entomologica Bohemoslovaca. - 1978. - Vol. 75. - P. 319-329.

Soldán, T., Zahrádková, S. Ephemeroptera of the Czech Republic: Atlas of Distribution. - Brno: Masaryk University, 2000. $-401 \mathrm{p}$.

Solem, J. O. Diel rythmic pattern of Leptophlebia marginata L. and L. vespertina L. (Ephemeroptera) // Aquilo, Series Zoologica. - 1973. - Vol. 14. - P. 80-83.

Sowa, $R$. Ecology and biogeography of mayflies of running water in the polish part of the Carpathians. 2. Life cycle // Acta Hydrobiologica. - 1975. - Vol. 17, N 4. - P. 319-353.

Tools - Search and find - Gesucht - Gegunden [Електронний ресурс] A. Haybach // Ephemeroptera Germanica. - 2012. - режим доступу: http://goo.gl/s52Zbs.

Життєві цикли одноденок (Insecta: Ephemeroptera) Східної України. Друге повідомлення. Мартинов, О. В. - Дана стаття $є$ другим повідомленням про результати дослідження життєвих циклів одноденок Східної України. Показано, що для представників різних родин необхідно використовувати різні методи визначення віку личинок. У роботі наведено дані щодо особливостей життєвих циклів 18 видів одноденок, для п'яти з них (Cloeon dipterum, Centroptilum luteolum, Paraleptophlebia submarginata, Ecdyonurus dispar gratificus та Ephemera vulgata) детально вивчено особливості зміни вікової структури личинок протягом року у модельних водоймах. Наведено періоди льоту імаго досліджених видів в межах Східної України. Описані деякі особливості роїння самців Leptophlebia marginata та Kageronia fuscogrisea. Показано, що в межах регіону рідкісний європейський вид Metreletus balcanicus має моновольтинний життєвий цикл, і зимує на стадії яйця (Us). Встановлено, що у межах Східної України яйцеживородний Cloeon dipterum має 2-3 генерації на рік (MBMP); вольтинність залежить, головним чином, від температурного режиму кожної конкретної водойми у якій вид проходить розвиток. Більша частина популяції моновольтинного Ecdyonurus dispar gratificus зимує на стадії яйця, менша частина - на стадії личинки (Uw-Us).

Ключові слова: одноденки, Ephemeroptera, життєві цикли, біономія, вольтинність, Східна Україна.

Адреса для зв'язку: О. В. Мартинов; Національний науково-природничий музей Національної академії наук України; вул. Богдана Хмельницького 15, Київ, 01601 Україна; e-mail: martynov_av@ukr.net. 